\title{
Pemanfaatan Daun Kelakai Sebagai Teh Penambah Darah
}

\section{Made Agustina Dwi Rahayu}

SMAN 2 Banama Tingang, Jln. Lintas P. Raya - K. Kurun Desa Hanua, Pulang Pisau, Kalimantan Tengah, Indonesia

Madedwi91@yahoo.co.id

\begin{abstract}
Abstrak. Kelakai di Kalimantan Tengah memiliki sebaran yang sangat banyak dan umumnya belum banyak dimanfaatkan. Kelakai yang digunakan untuk mengobati anemia pada zaman dulu belum pernah diteliti, tetapi memberikan bukti yang nyata secara empiris (etnobotani). Dari hasil penelitian oleh Dessy Maulidya Maharani, Siti Noor Haidah, Haiyinah (2005 dalam Studi Potensi Kelakai (Stenochlaena palustris (BURM.F) BEDD), sebagai pangan fungsional menghasilkan data dan membuktikan bahwa pada daun kelakai memiliki kandungan tinggi mineral Kalsium dan Besi. Kandungan besi pada daun kelakai yaitu 291,32 mg/100 mg bahan, hal ini memungkinkan daun kelakai berkhasiat sebagai pencegah anemia atau sebagai penambah darah. Penggunaan daun kelakai sebagai bahan baku pembuatan teh, memberikan alternatif pilihan untuk mendapatkan manfaat dari kandungan daun kelakai.
\end{abstract}

Kata kunci: daun kelakai, teh, penambah darah

\section{PENDAHULUAN}

Potensi lahan basah di Indonesia masih belum banyak tergali. Kalimantan Tengah merupakan daerah yang mempunyai sebaran lahan rawa (rawa air tawar dan rawa gambut) yang cukup luas, yaitu 3.01 juta ha atau $52.2 \%$ dari seluruh luasan gambut di Kalimantan (Anderson, 1972 MacKinnon et al (2000)).

Lahan rawa yang cukup luas itu ditumbuhi oleh berbagai macam jenis paku-pakuan, dan salah satunya tumbuhan Kelakai (Stenochlaena palustris). Kelakai merupakan paku tanah, yang memiliki panjang 5-10 m dengan akar rimpang yang memanjat tinggi, kuat, pipih, persegi, telanjang atau bersisik kerap kali dengan tunas yang merayap, tumbuhnya secara perlahan atau epifit dengan akar utama bearada di tanah.

Kelakai (Stenochlaena palustris) memiliki kandungan protein dan lemak, masing-masing 11,48\% dan 2,63\%. Dimana dengan adanya kadar protein yang tinggi maka tanaman kelakai dapat menjadi salah-satu sumber asupan protein 
nabati bagi masyarakat yang mengkonsumsinya. Daun kelakai juga memiliki kandungan tinggi mineral kalsium dan besi. Kandungan besi pada daun kelakai yaitu 291,32 mg/100 g bahan, hal ini memungkinkan daun kelakai berkhasiat sebagai pencegah anemnia atau sebagai penambah darah.kandungan yang terdapat pada kelakai, terutama kandungan Fe yang tinggi dan belum dimanfaatkan dengan baik, maka saya mencoba membuat varian baru sebagai obat penambah darah dengan membuat teh celup dari daun kelakai sebagai bahan utamanya. Pemanfaatan bahan alami daun kelakai (Stenochlaena palustris) sebagai bahan baku the penambah darah.

Penelitian ini bertujuan untuk memanfaatkan daun kelakai (Stenochlaena palustris) sebagai bahan baku teh penambah darah. Hasil penelitian ini dapat meningkatkan pemanfaatan daun kelakai (Stenochlaena palustris) dan menjadi salah satu alternative dalam menjaga kesehatan tubuh.

\section{METODE PENELITIAN}

Metode penelitian yang kami gunakan adalah metode kepustakaan dengan cara mengumpulkan data - data dari penelitian yang sudah ada mengenai daun kelakai (Stenochlaena palustris). Penelitian dilaksanakan sejak tanggal 10 Oktober sampai 30 November 2016 di SMAN 2 Banama Tingang.

\section{Alat dan Bahan Penelitian}

a. Alat yang digunakan adalah pisau, gunting, blender, nampan, jarum, benang

b. Bahan yang digunakan adalah daun kelakai, jahe, dan kayu secang

\section{Langkah Kerja}

1. Mengeringkan daun kelakai (Stenochlaena palustris), jahe, dan serutan kayu secang

2. Menghaluskan daun kelakai, jahe, dan serutan kayu secang yang sudah dikeringkan dengan cara diblender.

3. Memasukkan semua bahan yang sudah dihaluskan tersebut kedalam kertas saring yang sudah disiapkan. 


\section{HASIL PENELITIAN DAN PEMBAHASAN}

Anemia adalah suatu kondisi tubuh yang terjadi ketika sel - sel darah merah (eritrosit) dan/ atau hemoglobin $(\mathrm{Hb})$ yang sehat dalam darah berada di bawah nilai normal (kurang darah). Salah satu faktor resiko meingkatkan peluang sesorang untuk terkena anemia adalah kekurangan zat besi. Pada ibu hamil resiko anemia menjadi lebih besar karena zat besi yang dimiliki oleh ibu diguankan dalam peningkatan volume darah serta pembentukan hemoglobin jani yang dikandungnya.

Kelakai (Stenochlaena palustris) memiliki kandungan zat besi yang cukup tinggi. Besi merupakan bagian dari molekul hemoglobin $(\mathrm{Hb})$ yang berfungsi untuk mengangkut oksigen $(\mathrm{O} 2)$ dari paru-paru dan mendistribusikannya ke selsel yang membutuhkan untuk selanjutnya digunakan dalam metabolisme karbohidrat. protein. dan lemak menjadi energi (ATP) . Defisiensi zat besi pada manusia dapat menyebabkan turunnya sintesis sel darah merah yang akan mengakibatkan anemia. Kandungan Fe yang cukup tinggi pada kelakai sebesar $291,32 \mathrm{mg} / 100 \mathrm{~g}$ bahan diyakini dapat membantu mengatasi anemia yang dialami oleh kita. Kelakai dijadikan bahan baku pembuatan teh memberikan alternative lain untuk memperoleh manfaat kandungan Fe dalam kelakai.

\section{SIMPULAN}

Pemanfaatan daun kelakai sebagai bahan baku pembuatan teh dapat dijadikan sebagai salah satu alternative pemanfaatan kandungan Fe dalam kelakai sebagai penambah darah.

\section{DAFTAR RUJUKAN}

Maharani, D. M., S. N. Haidah, \& Hainiyah.2006. Studi Potensi Kalakai (Stenochlaena palustris (Burm.F) Bedd) sebagai Pangan Fungsional. Kumpulan Makalah PIMNAS XIX. Malang.

Suhartono, E., \& Adenan. (2010). Stenochlaena palustris aqueous extract reduces hepatic peroxidative stress in Marmota caligata with induced fever.Universa Medicina, 29(3), 123-128.

Sutomo(2010). KELAKAI. (on. line) http://biologitumbuhanlahanbasah .blogspot.co.id/2012/10/kelakaistenochlaena-palustris. (diakses tanggal 5April 2017)

Suwarno, M., Astawan, M., Wresdiyati, T., Widowati, S., Bintari, S., \& Mursyid. (2014). Evaluasi keamanan tepung tempe dari kedelai transgenik melalui uji subkronis dengan tikus percobaan maryani suwarno, 15(3), 353-362. 